\title{
Bis-(1-phenyl-5-nitro-6-methylthio-1,2,3,4-tetrahydropyrimidinyl)benzene and Bis-(1-phenyl-5-nitro-6-methylthio-1,2,3,4-tetrahydropyrimidinyl)diphenyl
}

\author{
Milan C. Dutta, Kaushik Chanda, Kaushal Kishore, J.N. Vishwakarma* \\ Organic Research Lab, Department of Chemistry, St. Anthony's College, \\ Shillong-793 001 (India) \\ Phone: 0364.2229928, Fax: 0364.2229558, e-mail: jnvishwakarma@rediffmail.com
}

Received: 21 May 2004 / Accepted: 1 June 2004 / Published: 1 August 2005

Keywords: nitroketene S, N-acetal, cyclocondensation, 1,2,3,4-tetrahydropyrimidine.

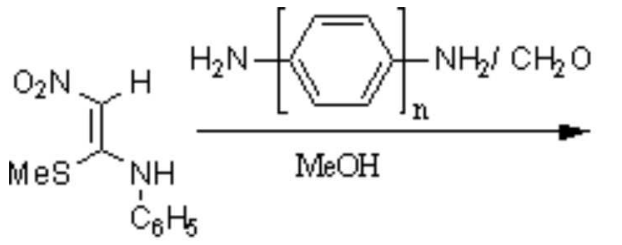

1

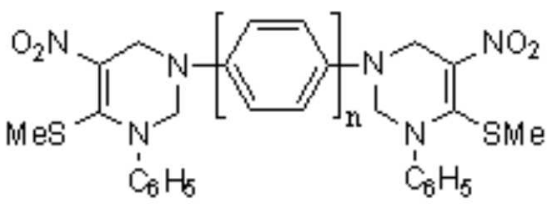

2a, $n=1 ; 2 \mathbf{b}, n=2$

In continuation with our on going program on the synthesis of tetrahydropyrimidines $[1,2]$, we have recently reported the synthesis of Bis-tetrahydropyrimidines [3] in which the rings are linked through flexible aliphatic chains. We now report the synthesis of the title compounds in which the rings are bonded through rigid aromatic systems. A mixture of p-phenylenediamine ( $54 \mathrm{mg}, 0.5 \mathrm{mmol})$ and formaldehyde (60 mg, $2 \mathrm{mmol}, 40 \%$ solution) was stirred in methanol (3 mL) for ten minutes and to this a solution of 1-nitro-2-anilino-2-methylthioethene 1 [4] (210 mg, $1 \mathrm{mmol})$ in $6 \mathrm{~mL}$ methanol was added and the mixture was stirred at room temperature for 5 hours, when a yellow solid precipitated out. After the completion of the reaction (monitored by tlc) the reaction mixture was cooled in ice water and the solid filtered, washed with methanol $(2 \mathrm{X} 2 \mathrm{~mL})$ to give pure $\mathbf{2 a}(220 \mathrm{mg}, 76 \%)$, which was recrystallized from methanol. The reaction of $\mathbf{1}$ with benzidine was carried out in refluxing methanol to give $\mathbf{2 b}$ in $63 \%$ yield, which was recrystallized from benzene.

\section{1,4-Bis-(1-phenyl-5-nitro-6-methylthio-1,2,3,4-tetrahydropyrimidinyl)benzene (2a)}

Melting point: $168-169^{\circ} \mathrm{C}$ (methanol, uncorrected).

IR $\left(\mathrm{KBr}, \mathrm{cm}^{-1}\right): 1456 ; 1503 ; 1544 ; 1611$.

${ }^{1} \mathrm{H}-\mathrm{NMR}\left(300 \mathrm{MHz}, \mathrm{CDCl}_{3}\right): \delta=1.94\left(\mathrm{~s}, 6 \mathrm{H}, \mathrm{SCH}_{3}\right) ; 4.49\left(\mathrm{~s}, 4 \mathrm{H}, \mathrm{N}-\mathrm{CH}_{2} \mathrm{C}=\right) ; 4.87\left(\mathrm{~s}, 4 \mathrm{H}, \mathrm{N}-\mathrm{CH}_{2}-\mathrm{N}\right)$; 6.70-6.73 (m, 4H); 7.06-7.33 (m, 10H).

${ }^{13} \mathrm{C}-\mathrm{NMR}\left(75 \mathrm{MHz}, \mathrm{CDCl}_{3}\right): \delta=16.5 ; 48.8 ; 72.1 ; 116.5 ; 124.8 ; 126.4 ; 127.3 ; 129.8 ; 133.2 ; 145.5 ; 146.0$; 160.2.

$\operatorname{MS}(\mathrm{m} / \mathrm{z}): 577\left(\mathrm{M}^{+}\right)$. 
Melting point: $167-169^{\circ} \mathrm{C}$ (benzene, uncorrected).

IR $\left(\mathrm{KBr}, \mathrm{cm}^{-1}\right): 1430 ; 1514 ; 1540 ; 1591$.

${ }^{1} \mathrm{H}-\mathrm{NMR}\left(300 \mathrm{MHz}, \mathrm{CDCl}_{3}\right): \delta=1.94\left(\mathrm{~s}, 6 \mathrm{H}, \mathrm{SCH}_{3}\right) ; 4.49\left(\mathrm{~s}, 4 \mathrm{H}, \mathrm{N}-\mathrm{CH}_{2} \mathrm{C}=\right) ; 4.87\left(\mathrm{~s}, 4 \mathrm{H}, \mathrm{N}-\mathrm{CH}_{2}-\mathrm{N}\right)$;

6.70-6.73 (m, 4H); 7.14-7.36 (m, 14H).

${ }^{13} \mathrm{C}-\mathrm{NMR}\left(75 \mathrm{MHz}, \mathrm{CDCl}_{3}\right): \delta=16.5 ; 48.8 ; 72.1 ; 116.5 ; 124.8 ; 126.4 ; 127.3 ; 128.3 ; 129.8 ; 133.2 ; 145.5 ;$ $146.0 ; 160.2$.

$\operatorname{MS}(\mathrm{m} / \mathrm{z}): 653\left(\mathrm{M}^{+}\right)$

\section{Acknowledgements:}

The authors wish to thank Fr. I. Warpakma for facilities and Fr. Stephan Mavely \& Fr. J. Nellanatt for encouragement. Financial assistance from ICAR-NATP is gratefully acknowledged. The authors also wish to express their gratitude to Dr. Anubrata Das of ICAR for his keen interest in this investigation.

\section{References:}

1.Vishwakarma, J.N.; Mofizuddin, M.; Ila, H.; Junjappa, H. J. Heterocyclic Chem. 1988, 25, 1387.

2.Karim, E.; Kishore, K.; Vishwakarma, J.N. J. Heterocyclic Chem. 2003, 40, 901-03.

3.Chanda, K.; Dutta, M.C.; Kishore, K.; Vishwakarma, J.N. Molbank, 2004, M367.

4.Gompper, R.; Schaefer, H. Chem. Ber. 1967, 100, 591-604.

Sample Availability: Available from MDPI.

(C) 2005 MDPI. All rights reserved. 